\title{
Assessing the Soil Nutrients of the Akanu Ibiam Federal Polytechnic Unwana, Nigeria
}

\author{
L.O. Ajala ${ }^{1}$, C.E. Ominyi ${ }^{2} \&$ I.O. Odewale ${ }^{3}$ \\ ${ }^{1 \& 2}$ Department of Science Laboratory Technology Akanu Ibiam Federal Polytechnic, Unwana, Nigeria. \\ ${ }^{3}$ Department of Ceramic and Glass Technology Akanu Ibiam Federal Polytechnic, Unwana, Nigeria.
}

\begin{abstract}
A wide range of minerals are found in the soil as natural occurring and purposely added elements as well as by adventitious contamination. These mineral elements can generally be classified as nutritionally essential major elements, nutritionally essential minor and trace elements, and those regarded as toxic with an essential/toxic duality. An investigation was carried out regarding the concentrations of some of these nutritionally essential elements in the soil samples from Akanu Ibiam Federal Polytechnic, Unwana, Nigeria. The results revealed the presence of some of these mineral elements studied in moderate concentrations in the locations sampled. The study also showed that the institution soil is of low fertility and therefore recommend the use of fertilizers to improve its fertility and hence increase crops yield.
\end{abstract}

Keywords: Unwana soil, mineral elements, fertilizers, nutrient deficiency, agricultural yield.

\subsection{Soil and soil formation}

\section{Introduction}

Soil is a mixture of organic and inorganic solid, air, water and microorganisms. The importance of soil depends largely on its properties such as structure, texture, colour, $\mathrm{pH}$, air, water content, minerals, organic materials and host of others [1]. Soil predominantly contains particles initially derived from the disintegration or decomposition of primary igneous rocks. But these particles may have been produced at an earlier geological period, moved by wind, water or ice over considerable distances and been through one or more cycles of erosion and decomposition[2]. Soil consists of four parts: mineral matter derived from the rocks, calcium carbonate and residual organic compound, residues of plants and microorganisms recently added to the soil and the soil water.

\subsection{Soil Organic Matter (SOM)}

Soil organic matter is any material produced originally by living organisms (plants or animals) that is returned to the soil and goes through the decomposition process [3]. It is an accumulation of dead plant materials partially decayed and re-synthesized plants and animal residues. Rapid decomposition of freshly fallen leaves and drying roots and the residues becomes part of soil humus - some portion of which remains in the soil for a very long time. Humus is the organic material that has been transferred into relatively stable form by soil microorganisms. SOM consists of crops residues, weeds, grasses, tree leaves, worms, bacteria, fungi and acetinomycetes [3]. However, SOM can be grouped into two: strongly coloured humic matter and non-humic matter - undecomposed plants remain. Organic matter contributes to plants growth through its effect on the chemical, biological and physical properties of the soil. The SOM supplies N, P and S for plant growth, serves as an energy source for soil micro floral and macro fauna organisms and promotes good soil structure [4]. Indirectly, human affects the plant's uptake of micronutrients and heavy metal cations and the performance (availability) of herbicides and other agricultural chemicals.

The factors that affect SOM are:

Climate: temperature, precipitation and evaporation.

Parent material: mineralogy, grain size, landscape form.

Organisms: vegetation, animals, microorganisms.

Topography: slope, altitude.

Time: start of soil formation and climatic change [5]

\subsection{Essential elements in the Soil}

Virgin soil usually contains adequate amounts of all the elements required for proper plants nutrition. There are a number of such nutrients for plants proper growth and fruitfulness. According to Alison [6], the chemical elements are 35 in number while 16 of them are called essential elements which are group as follows: trace elements that are required in specific condition which includes $\mathrm{Mn}, \mathrm{Mo}, \mathrm{Cu}, \mathrm{B}, \mathrm{Zn}, \mathrm{Fe}$ and $\mathrm{Cl}$. The other categories (major elements) which are required in large quantity are subdivided into: natural to include $\mathrm{C}, \mathrm{H}$ and $\mathrm{O}$; primary $(\mathrm{N}, \mathrm{P} \& \mathrm{~K})$ and secondary $(\mathrm{Ca}, \mathrm{Mg} \& \mathrm{~S})$ [6]. Of the required nutrients; $\mathrm{C}, \mathrm{H} \& \mathrm{O}$ are supplied in inexhaustible form by air and water. They are essential during the process of photosynthesis. Nitrogen is present 
Assessing The Soil Nutrients Of The Akanu Ibiam Federal Polytechnic Unwana, Nigeria

in enormous quantities in the atmosphere, but plants are not able to utilize it in this form, bacteria provide nitrogen from the air to the plants of the legumes family through the process called Nitrogen Fixation [7].

\subsection{Objective of the study}

The performance, growth and plants' yield give an ideal about the structure and composition of the soil.

The plant takes up its need from the surrounding soil. It signifies that plants interact with their immediate environment. It is a known fact that there is a direct relationship between the relative abundance of soil nutrients and the crop yields.

Despite the low crop yield on this Polytechnic soil, there has been no meaningful research on it. This research was therefore carried out centrally to evaluate some mineral elements in soil samples from Akanu Ibiam Federal polytechnic Unwana, Nigeria, with a view to assessing their nutritional level. This will go in long way to improve the agricultural products in the polytechnic community.

\section{Experimental}

\subsection{Sample collection}

Soil samples were collected from four different areas within the Polytechnic environment between $8^{\text {th }}$ $9^{\text {th }}$ of December, 2010. The locations are:

Information and Communication Centre location coded 'IC'

The School Administrative Block location coded 'AB'

The Governing Council Chamber location coded ' $G C$ '

Student Hostel/Centre location coded 'SH'

The samples were collected with a hand garden trowel. At the studied locations, a random sampling technique was used to collect representative composite soil samples from the pre-classified sites at a depth of 5$20 \mathrm{~cm}$. The samples were air-dried, sieved with 60 mesh size $(0.25 \mathrm{~mm})$ and later stored separately in black polythene bags prior to analysis.

\subsection{Chemical analysis}

The available Potassium was determined by ammonium acetate extraction method at $\mathrm{pH} 9$ as described by Gbenjo et al [8]. Total Nitrogen was measured using Kjeldahl technique (Kjeltech 2300) [9]. Phosphorus was determined with the aid of spectrophotometer by the method of Mehlich [10]. Magnesium, Calcium, Iron, Manganese, Copper, Zinc and Cobalt were analyzed with Atomic Absorption Spectrophotometer (Buck 210) $[8,11]$.

\section{Results}

The results of the analysis are presented in the table below. The results of some macro and micro nutrients present in the soil sample from Akanu Ibiam Federal Polytechnic, Unwana, Nigeria.

\begin{tabular}{|l|c|c|c|c|c|c|}
\hline Element $(\mathbf{m g} / \mathbf{k g})$ & GC & $\mathbf{A B}$ & IC & SH & Mean value & Ideal value \\
\hline Calcium $(\mathrm{Ca})$ & 1.527 & 0.503 & 0.057 & 0.096 & 0.546 & $1150-3500$ \\
\hline Magnesium $(\mathrm{Mg})$ & 17.89 & 15.69 & 12.76 & 6.07 & 13.103 & -- \\
\hline Potassium $(\mathrm{K})$ & 58.40 & 58.20 & 53.30 & 23.40 & 48.325 & $59-160$ \\
\hline Boron $(\mathrm{B})$ & 0.395 & 0.296 & 0.227 & 0.11 & 0.257 & -- \\
\hline Manganese $(\mathrm{Mn})$ & 2.45 & 1.55 & .087 & 1.51 & 1.595 & 14 \\
\hline Iron $(\mathrm{Fe})$ & 4070 & 2400 & 1560 & 670 & 2175 & 90 \\
\hline Copper $(\mathrm{Cu})$ & 2.484 & 1.093 & 0.976 & 0.654 & 1.302 & $2-6$ \\
\hline Zinc $(\mathrm{Zn})$ & 2.82 & 4.67 & 2.30 & 1.405 & 2.799 & 4 \\
\hline Nitrogen $(\mathrm{N})$ & 0.47 & 0.39 & 0.456 & 0.47 & 0.447 & $0.8-1.5$ \\
\hline Phosphorus $(\mathrm{P})$ & 0.05 & 0.02 & 0.15 & 0.08 & 0.075 & -- \\
\hline
\end{tabular}

\section{Discussions}

The table above shows the concentrations of the elements in the selected locations from the soil samples from Akanu Ibiam Federal Polytechnic, Unwana, Nigeria. The last column, according to Ibitoye [12], represents the macro and micro elements and their respective ideal/moderate concentrations needed in the soil for proper plants growth.

Comparing the results from the sampling sites, soil sample from ' $\mathrm{GC}$ ' was the most fertile because it had highest concentrations of NPK notation for the most essential elements for plants' growth [13]. Comparing the results again with the ideal concentration of nutrient elements for proper plants' growth, the results showed that all the sampling sites are less fertile. This might be as a result of continuous cropping practice on the same land year in year out. Therefore, the land needs effective use of fertilizers for soil replenishment with nutrients for good agricultural yield. This is observed in the yield of the crops planted on the soil; since micronutrients' 
deficiencies in the soil is one of the yields limiting factors [14].

All the sampled sites had relatively low concentration of phosphorus with the highest value associated with soil sample from " $\mathrm{GC}$ ' with a value of $0.15 \mathrm{mg} / \mathrm{kg}$ and the least found in the soil sample from 'SH' $(0.02 \mathrm{mg} / \mathrm{kg})$. As a component of ATP, phosphorus is needed for the conversion of light energy to chemical energy (ATP) during photosynthesis. It can also be used to modify the activity of various enzymes by phosphorylation. Since ATP can be used for the biosynthesis of many plant biomolecules, phosphorus is important for plant growth and flower/seed formation $[2,6]$

Iron had a noticeable elevated level occurring in all the samples which were even higher than the required concentration in the soil $(90 \mathrm{mg} / \mathrm{kg})$. Iron belongs to the group of elements whose minimal dose is indispensable for the proper functioning of organisms and excessive amounts exert detrimental effects [15]. The high concentration in the soil of iron (and other heavy metals) exert negative effects on the growth and development of plants evoking disturbances in the absorption, transportation and assimilation of individual elements and contributing to changes reflected in reduced yields and fluctuating contents of some micro and macro elements $[16,17]$. The soil sample from ' $G C$ ' had the highest value of calcium $(1.527 \mathrm{mg} / \mathrm{kg})$ though low compare to the ideal value $(1150-3500 \mathrm{mg} / \mathrm{kg})$. It has been reported that calcium deficiency or excess may completely stop the growth and plants may die off [18].

Nitrogen is an essential component of all proteins. Nitrogen deficiency most often results in stunted growth. The contents in the soil sampled ranged from $0.39-0.47 \mathrm{mg} / \mathrm{kg}$. Magnesium is part of the chlorophyll in all green plants and essential for photosynthesis. It also helps activate many plant enzymes needed for growth. The values are moderate in all the samples and the mean concentration was found to be $13.103 \mathrm{mg} / \mathrm{kg}$.

Boron is important in sugar transport, cell division, and synthesis of certain enzymes. The mean value was found to be $0.257 \mathrm{mg} / \mathrm{kg}$. Boron deficiency causes necrosis in young leaves and stunting [12].

Copper is important for photosynthesis and involves in many enzyme processes. Its concentration in the soil sampled from ' $\mathrm{GC}$ ' $(2.484 \mathrm{mg} / \mathrm{kg})$ was in line with the ideal concentration $(2-6 \mathrm{mg} / \mathrm{kg})$. Other samples had relatively low concentrations though these values are still normal considering the acute toxicity of copper in excess but its deficiency in the soil causes plant chlorosis $[2,12]$.

Zinc is required in a large number of enzymes and plays an essential role in DNA transcription. The highest value was found from the soil sample from ' $\mathrm{SH}$ ' $(4.67 \mathrm{mg} / \mathrm{kg})$ and the lowest from 'AB' with a value of $1.405 \mathrm{mg} / \mathrm{kg}$. A typical symptom of zinc deficiency is the stunted growth of leaves, commonly known as "little leaf" and is caused by the oxidative degradation of the growth hormone auxin. Manganese is necessary for building the chloroplasts. The values from the sampling sites were relatively low compare to the ideal value $(14 \mathrm{mg} / \mathrm{kg})$. Manganese deficiency may result in coloration abnormalities, such as discolored spots on the foliage $[6,12]$.

\section{Conclusion}

The results of the analysis revealed that the representative sites had low concentrations of required elements for good agricultural yield. This might be as a result of geological composition of the soil of this environment or continuous cropping. It research has confirmed that the institution soil needs adequate fertilization for proper plant growth. On this note, it is therefore recommended that the soil should be nourished with fertilizers (especially NPK) to achieve more productivity. Also, because of deficiencies of most of these mineral elements in the soil sampled, further investigation should be conducted to determine heavy metal contents of the soil since their excessive concentrations in the soil hampered the absorption, transportation and assimilation of useful nutrients by the plants which are likely to result in diminished volume and deteriorated quality of yields. Hence, studies on heavy metals in the school soil and plant tissue testing of the crop growing on the soil are advocated.

\section{References}

[1] A. Youdeowei, F.O.C. Ezedinma and C.O. Ochapa, Introduction to tropical agriculture, 1st Ed (China: Longman Ltd., 1986) 70-72.

[2] E.W. Russell, Soil conditions and plant growth, 10th Ed (London: Longman Group Ltd., 1973) 60.

[3] B. Alexandra and B. Jose, The importance of soil organic matter. FAO Soils Bulletin, 2005, 5-6.

[4] W. Smilde, Soil organic matter and organic manuring, in G.R. Heren, Publication of institution for fertility (The Netherlands, 1978) $8-10$.

[5] V.I.E. Ajiwe, S.C. Mbekedogu, C.C. Ajiwe and H.O. Nnabuenyi, Analysis of micro and macro elements in Nnamdi Azikiwe University soil, Anachem Journal, 3(1 \& 2), 2008, 434-438.

[6] W. Alison, http://www.ncagr.gov/cyber/kidwrld/plant/nutrient.htm, 2005, Retrieved13/01/2011.

[7] I. Pais and J.B. Jones, The handbook of trace elements, in B. Ration (Ed) (Florida,19197) 1-202.

[8] I.O. Gbenjo, D.F. Latona, O.A.Oyetade, O. R. Adebayo and S.A. Shittu, Chemicals in Action: A laboratory manual of applied chemistry (Nigeria: Ajidek Press Ltd., 2009) 46.) 357- 359 \& 627.

[9] J. Mendham, R.C. Denney, J.D. Barnes and M.J.K. Thomas, Quantitative Chemical Analysis (Indian Delhi: Vogel, Singapore Ltd., 2002).

[10] M. Mehlich, Mehlich-3 soil test extractant: A modification of the Mehlich-2 extractant, Comm. Soil Sci. Plant Anal., 15, 1984, 1409-1416.

[11] G.I. Onwuka, Food Analysis and Instrumentation: Theory and Practice (Lagos, Nigeria: Naphthali Prints, 2005$) 115-121$. 
[12] A.A. Ibitoye, Laboratory methods on basic plant analysis (Nigeria: Concept IT and Edu. Consults, 2005), 25.

[13] M. Russel, Understanding Soil Nutrients, http://EzinneArticles.com/?expert=MichaelRussel, 2004, Retrieved24/01/2011.

[14] P. Rakkiyappan, S. Thongavelu and R. Radmani, Effect of ferrous sulphate on sugarcane varieties growth in iron deficiency soil, Sugar Technol., 4, 2002, 33-37.

[15] G.A. Pederson, E.B. Geoffrey and T.E. Fairbrother, Nutrient uptake in plants of sixteen forages fertilized with poultry litter, Agron. Journal, 94, 2002, 895-904.

[16] F. Gambus and E. Gorlach, Microelements in fertilization of plants, requirements and application, Mat.VII Symp. Micronutrients in Agriculture, AR. Woodow, Poland, 1992, 13-19.

[17] H. Obata and M. Umebayashi, Effects of cadmium on mineral nutrient concentrations in plants differing in tolerance of cadmium, Journal of Plant Nutr., 20, 1997, 97-105.

[18] S.K. Sigh and R.R. Singh, Management of nutritional disorders in sugarcane, Cooperative sugar, 34, 2003, 913-975. 